\title{
Sulfuricella denitrificans gen. nov., sp. nov., a sulfur-oxidizing autotroph isolated from a freshwater lake
}

\author{
Correspondence \\ Hisaya Kojima \\ kojimah@pop.lowtem.hokudai. \\ ac.jp
}

\author{
Hisaya Kojima and Manabu Fukui \\ Institute of Low Temperature Science, Hokkaido University, Kita-19, Nishi-8, Kita-ku, \\ Sapporo 060-0819, Japan
}

\begin{abstract}
A novel facultatively anaerobic, sulfur-oxidizing bacterium, strain skB26 ${ }^{\top}$, was isolated from anoxic water of a freshwater lake in Japan. The cells were rod-shaped, motile and Gram-negative. Strain skB26 ${ }^{\top}$ oxidized elemental sulfur and thiosulfate to sulfate as sole energy sources. Strain skB26 ${ }^{\top}$ was microaerobic and could also utilize nitrate as an electron acceptor, reducing it to nitrogen. Growth was observed at temperatures below $28^{\circ} \mathrm{C}$; optimum growth was observed at $22{ }^{\circ} \mathrm{C}$. The $\mathrm{pH}$ range for growth was 6.0-9.0, and the optimum $\mathrm{pH}$ was 7.5-8.0. Optimum growth of the isolate was observed in medium without $\mathrm{NaCl}$, and no growth was observed in medium containing more than $220 \mathrm{mM} \mathrm{NaCl}$. The $\mathrm{G}+\mathrm{C}$ content of genomic DNA was around $59 \mathrm{~mol} \%$.

Phylogenetic analysis based on the 16S rRNA gene sequence indicated that the strain was a member of the class Betaproteobacteria, and the closest cultivated relative was 'Thiobacillus plumbophilus' DSM 6690, with $93 \%$ sequence similarity. Phylogenetic analyses were also performed using sequences of genes involved in sulfur oxidation, inorganic carbon fixation and nitrate respiration. On the basis of its phylogenetic and phenotypic properties, strain skB26 ${ }^{\top}$ $\left(=\right.$ NBRC $105220^{\top}=$ DSM $\left.22764^{\top}\right)$ is proposed as the type strain of a novel species of a new genus, Sulfuricella denitrificans gen. nov., sp. nov.
\end{abstract}

Nitrogen and sulfur are essential for all organisms as major components of cell materials. There are also a variety of abundant inorganic compounds of these elements in the biosphere, with a wide range of redox states. These chemical species have specific properties, and biogeochemical cycling of the elements is largely dependent on dissimilatory and assimilatory activities of prokaryotes. Compounds of nitrogen and sulfur act as electron acceptors or donors for diverse types of respiration, and cycles of these elements are coupled directly by sulfuroxidizing bacteria, which utilize oxidized forms of nitrogen as electron acceptors. Phylogenetically diverse bacteria and archaea are capable of chemolithotrophic growth on reduced forms of sulfur, but the majority of isolated mesophilic species belong to the phylum Proteobacteria.

One of the major sources of reduced sulfur compounds in natural environments is sulfate reduction occurring under

Abbreviation: RuBisCO, ribulose-1,5-bisphosphate carboxylase/oxygenase.

The GenBank/EMBL/DDBJ accession number for the $16 \mathrm{~S}$ rRNA gene sequence of strain skB26 ${ }^{\top}$ is $A B 506456$; accession numbers for the partial aprA, soxB, cbbL, cbbM and nirS sequences of strain skB26 ${ }^{\top}$ are AB506457-AB506461.

Phylogenetic trees based on partial deduced amino acid sequences derived from $c b b L, c b b M$ and nirS gene sequences are available as supplementary material with the online version of this paper. oxygen- and nitrate-depleted conditions. This terminal process of mineralization takes place mainly in marine and lake sediments. These environments are often associated with low temperature, and the presence of cold-adapted sulfur oxidizers is expected in such habitats.

In the present study, a novel psychrotolerant, sulfuroxidizing, nitrate-reducing bacterium, strain $\mathrm{skB} 26^{\mathrm{T}}$, was isolated from cold anoxic water obtained from a freshwater lake. Based on the phylogenetic analysis, it was suggested that this strain represents a novel taxon in the class Betaproteobacteria.

Strain $\mathrm{skB} 26^{\mathrm{T}}$ was obtained from the hypolimnion of a meromictic freshwater lake, Lake Mizugaki, an artificial lake located in central Japan (Kojima et al., 2009). The water sample was obtained from a depth of $40 \mathrm{~m}$, approximately $3 \mathrm{~m}$ above the sediment surface. The water was characterized by depletion of oxygen, a smell of sulfide and low temperature $\left(5^{\circ} \mathrm{C}\right)$. The basal medium used for enrichment and isolation was a carbonate-buffered low-salt defined medium, modified from the medium for sulfatereducing bacteria (Widdel \& Bak, 1992). The modification included the elimination of sulfate and replacement of sulfide with thiosulfate as an alternate reductant and sulfur source. The composition of the medium was $\left(1^{-1}\right): 0.25 \mathrm{~g}$ $\mathrm{NaCl}, \quad 0.2 \mathrm{~g} \quad \mathrm{MgCl}_{2} .6 \mathrm{H}_{2} \mathrm{O}, 0.1 \mathrm{~g} \mathrm{CaCl}_{2} .2 \mathrm{H}_{2} \mathrm{O}, 0.1 \mathrm{~g}$ $\mathrm{NH}_{4} \mathrm{Cl}, 0.1 \mathrm{~g} \mathrm{KH}_{2} \mathrm{PO}_{4}, 0.1 \mathrm{~g} \mathrm{KCl}, 1 \mathrm{ml}$ trace element 
solution, $1 \mathrm{ml}$ selenite-tungstate solution, $1 \mathrm{ml}$ vitamin mixture, $1 \mathrm{ml}$ vitamin $B_{12}$ solution, $1 \mathrm{ml}$ thiamine solution, $30 \mathrm{ml} \mathrm{NaHCO}_{3}$ solution and $1.5 \mathrm{ml} \mathrm{Na} \mathrm{S}_{2} \mathrm{O}_{3}$ solution. All stock solutions were prepared as described by Widdel \& Bak (1992), and the preparation procedure for the medium was virtually the same as for the original medium. Before dispensing into glass bottles, the medium was adjusted to $\mathrm{pH}$ 7.0-7.2. Just before inoculation, anaerobic stock solutions of $\mathrm{NaNO}_{3}$ and $\mathrm{Na}_{2} \mathrm{~S}_{2} \mathrm{O}_{3}$ were added to the bottle to obtain final concentrations of 20 and $10 \mathrm{mM}$, respectively. To establish the first enrichment, $0.1 \mathrm{ml}$ lake water was inoculated into $50 \mathrm{ml}$ medium. The headspace of the bottle was filled with $\mathrm{N}_{2} / \mathrm{CO}_{2}(80: 20$, v/v) and incubation was performed in the dark at $22{ }^{\circ} \mathrm{C}$. A wellgrown culture ( $1 \%$ volume of fresh medium) was transferred to medium of the same composition to obtain subsequent enrichment cultures. Throughout the cultivation, $\mathrm{N}_{2} / \mathrm{CO}_{2}$-flushed syringes were used to transfer cultures. A pure culture of the strain was obtained from the fifth enrichment by using agar shake dilution (Widdel \& Bak, 1992). Purity of the isolate was tested by phasecontrast light microscopy, transferring to various media containing organic compounds and sequencing of $16 \mathrm{~S}$ rRNA gene fragments amplified with several universal PCR primer pairs.

The morphology of the isolate was observed under phasecontrast microscopy. Gram staining was conducted with a commercially available kit (Fluka). Activity of catalase was assessed by pouring a $3 \% \mathrm{H}_{2} \mathrm{O}_{2}$ solution onto a pellet of cells obtained by centrifugation. Oxidase activity was also tested with a pellet of cells, by using a differentiation disc (Fluka).

The basal medium containing $20 \mathrm{mM} \mathrm{NaNO}_{3}$ and $10 \mathrm{mM}$ $\mathrm{Na}_{2} \mathrm{~S}_{2} \mathrm{O}_{3}$ was used throughout the characterization of the strain, and cultures were incubated at $22{ }^{\circ} \mathrm{C}$ unless otherwise specified. For testing of electron donor utilization, the concentration of $\mathrm{Na}_{2} \mathrm{~S}_{2} \mathrm{O}_{3}$ in the medium was reduced to $0.4 \mathrm{mM}$ and $20 \mathrm{mM} \mathrm{NaNO}$ was used as an electron acceptor. Utilization of electron acceptors was tested in medium with nitrate omitted. The effect of $\mathrm{NaCl}$ concentration was tested with modified media containing varying concentrations of $\mathrm{NaCl}$. To test the effect of $\mathrm{pH}$ on growth, modified media ( $\mathrm{pH}$ 5.5-9.0) were also prepared with $\mathrm{HCl}$ or $\mathrm{Na}_{2} \mathrm{CO}_{3}$. Growth under different conditions was assessed by monitoring changes in concentrations of nitrate, sulfate and thiosulfate with ion chromatography. Sensitivity to antibiotics was tested for $100 \mu \mathrm{g}$ kanamycin and ampicillin $\mathrm{ml}^{-1}$.

The $\mathrm{G}+\mathrm{C}$ content of the genomic DNA was determined with the fluorescence monitoring method (Gonzalez \& Saiz-Jimenez, 2002) by a using real-time PCR apparatus (MiniOpticon; Bio-Rad).

The nearly full-length $16 \mathrm{~S}$ rRNA gene was amplified with the primers $27 \mathrm{~F}$ and 1492R (Lane, 1991) and the PCR product was then directly sequenced. Partial fragments of functional genes were also amplified with appropriate primer pairs and then sequenced directly. The analysed genes tested are involved in sulfur oxidation $(\operatorname{soxB}$, encoding sulfate thioesterase/sulfate thiohydrolase, and aprA, encoding adenosine- 5 '-phosphosulfate reductase), inorganic carbon fixation [ $c b b L$ and $c b b M$, encoding forms I and II, respectively, of ribulose-1,5-bisphosphate carboxylase/oxygenase (RuBisCO)] and nitrate respiration (nirS, encoding cytochrome $c d_{1}$ nitrite reductase). The soxB and aprA gene fragments were amplified with the primer pairs soxB693F/soxB1446B (Meyer et al., 2007) and Apr-1FW/Apr-5-RV (Meyer \& Kuever, 2007a), respectively. Amplification of the genes encoding the two forms of RuBisCO was performed as described previously (Elsaied \& Naganuma, 2001). For amplification of nirS, the primer pair cd3aF/R3cd (Throbäck et al., 2004) was used. The $16 \mathrm{~S}$ rRNA gene sequence of $\mathrm{skB} 26^{\mathrm{T}}$ was aligned with related sequences retrieved from the DDBJ/EMBL/GenBank databases using the program CLUSTAL_X (Thompson et al., 1997). Genetic distances were calculated using the program MEGA3 (Kumar et al., 2004). In the phylogenetic analyses of the functional genes, nucleotide sequences were translated to amino acid sequences and the deduced sequences were aligned with related sequences from the databases. Based on the resulting alignment, genetic distances were calculated using the model of Poisson correction. Phylogenetic trees were constructed using the neighbour-joining, minimum-evolution and maximum-parsimony methods and the robustness of the each tree was examined with bootstrap tests of 1000 replicates.

Cells of isolate $\mathrm{skB} 26^{\mathrm{T}}$ were Gram-negative, straight rods (0.8-2.0 $\mu \mathrm{m}$ long and $0.4-0.6 \mu \mathrm{m}$ wide) and exhibited motility. Spore formation was not observed. The catalase test was negative, while the oxidase test was positive. Growth of the isolate was inhibited by kanamycin and ampicillin. The $\mathrm{G}+\mathrm{C}$ content of the genomic DNA of the isolate was $59.0 \mathrm{~mol} \%$.

In the presence of nitrate, heterotrophic growth of strain skB26 $6^{\mathrm{T}}$ on the following substrates was tested and none of them supported growth: methanol, formate, pyruvate, citrate, lactate, acetate (all $5 \mathrm{mM}$ ), lactose, propionate, glucose, succinate, ethanol, fumarate, xylose, malate, benzoate, butyrate, isobutyrate (all $2.5 \mathrm{mM}$ ) and yeast extract $(0.02 \%$; Difco). The isolate could grow chemolithotrophically on thiosulfate $(10 \mathrm{mM})$ and $S^{0}\left(0.5 \mathrm{~g} \mathrm{l}^{-1}\right)$, generating sulfate as the end product. Growth on inorganic sulfur compounds other than thiosulfate was tested for sulfide $(1.0,2.0,2.9$ and $7.4 \mathrm{mM})$, sulfite $(5 \mathrm{mM})$ and tetrathionate $(10 \mathrm{mM})$, but none of these supported growth of strain $\mathrm{skB26} 6^{\mathrm{T}}$. Autotrophic growth on other inorganic electron donors was tested $\left[\mathrm{H}_{2}\left(\mathrm{H}_{2} / \mathrm{N}_{2} / \mathrm{CO}_{2}\right.\right.$, 50:40:10 by vol.; $200 \mathrm{kPa}$ total pressure) and $\mathrm{FeSO}_{4}$ $(20 \mathrm{mM})$ ], but no growth was observed.

Electron acceptor utilization was tested with $10 \mathrm{mM}$ thiosulfate as an electron donor. During growth by nitrate reduction, gas production was observed and accumulation of nitrite was not detected. Aerobic and microaerobic 


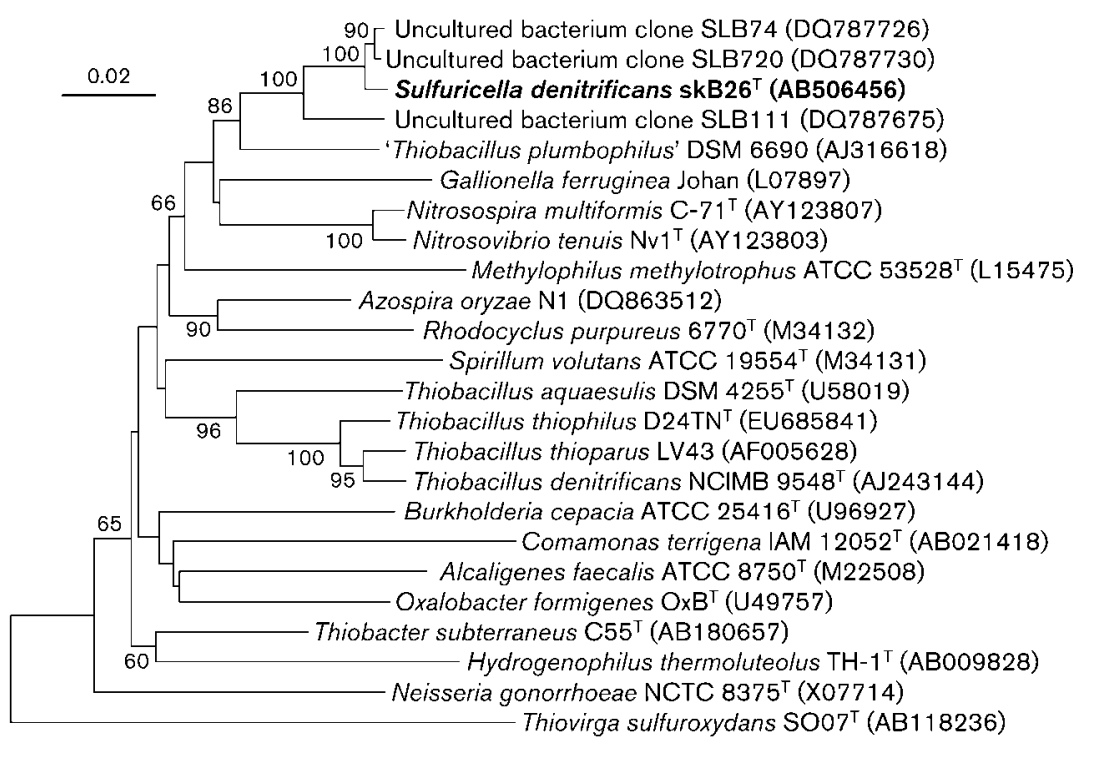

Fig. 1. Phylogenetic position of skB26 $6^{\top}$ within the class Betaproteobacteria, based on $16 \mathrm{~S}$ rRNA gene sequence analysis. The sequence of Thiovirga sulfuroxydans SO07 ${ }^{\top}$ (Gammaproteobacteria) was included as an outgroup. The tree was constructed with the minimumevolution method using 1298 positions. Numbers at nodes represent percentage values from 1000 bootstrap resamplings (values $>50 \%$ are shown). Bar, 0.02 substitutions per nucleotide position. growth were tested with varying concentrations of $\mathrm{O}_{2}(20$, 10 and $2 \%$ ) in the headspace. Growth was observed under all tested conditions, but growth under $20 \% \mathrm{O}_{2}$ was considerably slower than that under the other conditions. Growth of strain skB26 ${ }^{\mathrm{T}}$ was also supported by $\mathrm{N}_{2} \mathrm{O}(4 \%$ in the headspace). Utilization of nitrite ( 5 and $10 \mathrm{mM}$ ) was also tested, but it could not support growth of the isolate. Electron acceptor utilization was also tested with the alternative electron donor $S^{0}$, and the same results were obtained.

Growth of strain skB26 ${ }^{\mathrm{T}}$ was observed at temperatures lower than $28^{\circ} \mathrm{C}$, and optimum growth was observed at $22{ }^{\circ} \mathrm{C}$. The lower limit of temperature for growth was not determined, but psychrotolerance of the isolate was demonstrated by growth at $0{ }^{\circ} \mathrm{C}$. The range of initial $\mathrm{pH}$ for growth was 6.0-9.0, and the optimum $\mathrm{pH}$ was 7.5-8.0. Optimum growth of the isolate was observed in medium without $\mathrm{NaCl}$, and no growth was observed in medium containing more than $220 \mathrm{mM} \mathrm{NaCl}$.

Phylogenetic analysis of the $16 \mathrm{~S}$ rRNA gene sequence revealed strain $\mathrm{skB} 26^{\mathrm{T}}$ to belong to the class Betaproteobacteria. The closest cultivated relative of the novel strain was 'Thiobacillus plumbophilus' DSM 6690, an aerobic bacterium capable of chemolithotrophic growth on $\mathrm{H}_{2} \mathrm{~S}$, $\mathrm{H}_{2}$ and $\mathrm{PbS}$ (Drobner et al., 1992). The sequence similarity between skB26 ${ }^{\mathrm{T}}$ and 'T. plumbophilus' DSM 6690 was $93 \%$. Several environmental clones closely related to the novel strain have been reported from cold sediment of a meromictic lake (Nelson et al., 2007); these sequences formed a phylogenetic cluster distinct from the cluster comprising species of the genus Thiobacillus with validly published names (Fig. 1).

Highest similarity to 'T. plumbophilus' DSM 6690 was also observed in phylogenetic analyses of genes involved in sulfur oxidation, soxB and aprA (Figs 2 and 3). In the analysis of $\operatorname{sox} B$, the phylogenetic relationship among strain skB26 ${ }^{\mathrm{T}}$, 'T. plumbophilus' DSM 6690 and Thiobacillus species with validly published names was similar to that revealed by the $16 \mathrm{~S}$ rRNA gene sequence analysis (Fig. 2). For aprA, 'T. plumbophilus' DSM 6690 possesses two loci of differing sequences, which hindered direct sequencing of PCR products (Meyer \& Kuever, 2007b). In contrast, direct sequencing of the PCR product obtained from strain $\mathrm{skB} 26^{\mathrm{T}}$ resulted in successful acquisition of a single sequence, without ambiguity. The obtained sequence belonged to the cluster referred to as 'Apr lineage II' (Meyer \& Kuever, 2007b) (Fig. 3).

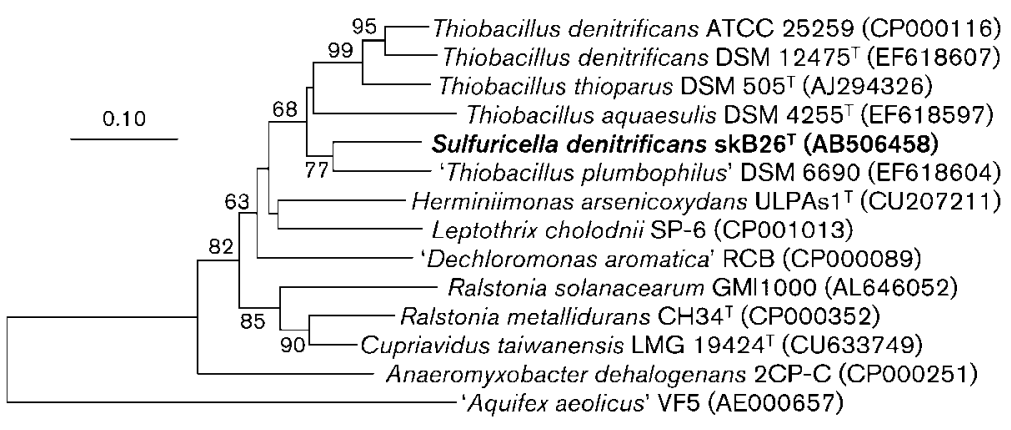

Fig. 2. Phylogenetic position of $s k B 26^{\top}$ based on $\operatorname{sox} B$ gene sequence analysis. This minimum-evolution tree was constructed from amino acid sequences deduced from soxB gene sequences (239 amino acid positions were used). Numbers at nodes are percentage values from 1000 bootstrap resamplings (values $>50 \%$ are shown). Bar, 0.1 substitutions per amino acid position. 


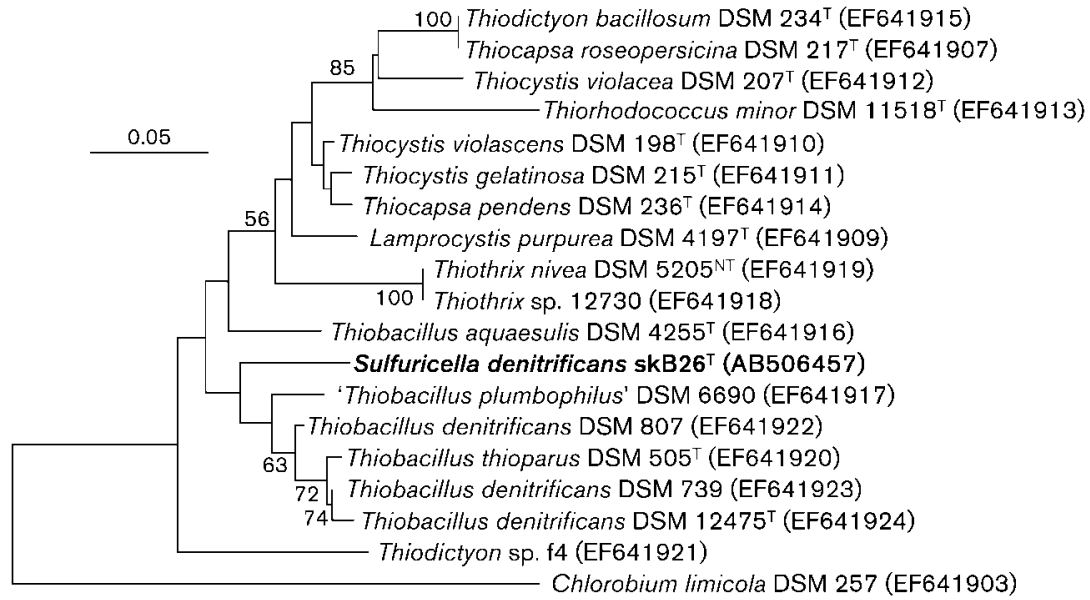

Fig. 3. Phylogenetic position of $\mathrm{skB} 26^{\top}$ based on aprA gene sequence analysis. This minimum-evolution tree was constructed from amino acid sequences deduced from aprA gene sequences (119 amino acid positions were used). Numbers at nodes are percentage values from 1000 bootstrap resamplings (values $>50 \%$ are shown). Bar, 0.05 substitutions per amino acid position.
Genes for two forms of RubisCO were detected and successfully sequenced from genomic DNA of strain $\mathrm{skB} 26^{\mathrm{T}}$. In the phylogenetic analysis of the large subunit of form I RubisCO, encoded by the $c b b L$ gene, the novel isolate clustered with beta- and gammaproteobacterial chemolithotrophs (Supplementary Fig. S1, available in IJSEM Online). A similar result was obtained from analysis of form II RubisCO, encoded by $c b b M$ (Supplementary Fig. S2). Sequences of these genes were not available for ' $T$. plumbophilus' in the public databases.

Denitrification ability of the isolate was supported by detection of the nirS gene. It has been shown that the phylogeny of this gene is only partially consistent with that based on the 16S rRNA gene, and the novel strain belonged to the cluster comprising betaproteobacteria (Supplementary Fig. S3).

Phylogenetic analyses of multiple genes indicated the novelty of strain skB26 $6^{\mathrm{T}}$. Among genera of sulfur-oxidizing bacteria, the genus Thiobacillus is the closest relative of the novel strain. However, strain skB26 $6^{\mathrm{T}}$ and its closest relative, 'T. plumbophilus' DSM 6690, are phylogenetically distinct from Thiobacillus species with validly published names (Fig. 1). In addition, these two organisms are quite different in their utilization of electron donors and acceptors. As electron donors to sustain growth, the novel strain could utilize thiosulfate and elemental sulfur; ' $T$. plumbophilus' DSM 6690 can grow on neither of these, and utilizes $\mathrm{H}_{2}$ and $\mathrm{H}_{2} \mathrm{~S}$, which could not sustain growth of skB26 ${ }^{\mathrm{T}}$. Furthermore, the novel isolate is facultatively anaerobic, whereas ' $T$. plumbophilus' DSM 6690 is strictly aerobic. On the basis of its phylogenetic and phenotypic properties, strain $\mathrm{skB} 26^{\mathrm{T}}$ is proposed to represent a novel species of a new genus, Sulfuricella denitrificans gen. nov., sp. nov.

\section{Description of Sulfuricella gen. nov.}

Sulfuricella [Sul.fu.ri.cel'la. L. neut. n. sulfur sulfur; L. fem. n. cella a small room and, in biology, a cell; N.L. fem. n. Sulfuricella sulfur(-oxidizing) cell].
Chemolithoautotrophic and grow by the oxidation of reduced sulfur compounds. Facultatively anaerobic. Based on 16S rRNA gene sequence analysis, affiliated phylogenetically to the class Betaproteobacteria. The type species is Sulfuricella denitrificans.

\section{Description of Sulfuricella denitrificans sp. nov.}

Sulfuricella denitrificans (de.ni.tri'fi.cans. N.L. v. denitrifico to denitrify; N.L. part. adj. denitrificans denitrifying).

Displays the following properties in addition to those described for the genus. Cells are Gram-negative rods, 0.8$2.0 \mu \mathrm{m}$ long and $0.4-0.6 \mu \mathrm{m}$ wide. Reduces nitrate to nitrogen. Autotrophic growth occurs with oxidation of thiosulfate and elemental sulfur to sulfate. Catalasenegative and oxidase-positive. Grows at temperatures lower than $28{ }^{\circ} \mathrm{C}$, with optimum growth at $22{ }^{\circ} \mathrm{C}$. The $\mathrm{pH}$ range for growth is 6.0-9.0; optimum growth occurs at $\mathrm{pH}$ 7.5-8.0. Does not require $\mathrm{NaCl}$ for growth, and does not grow at above $220 \mathrm{mM} \mathrm{NaCl}$. The $\mathrm{G}+\mathrm{C}$ content of genomic DNA of the type strain is $59 \mathrm{~mol} \%$.

The type strain, skB26 ${ }^{\mathrm{T}}\left(=\right.$ NBRC $\left.105220^{\mathrm{T}}=\mathrm{DSM} 22764^{\mathrm{T}}\right)$, was isolated from anoxic lake water of a stratified freshwater lake.

\section{Acknowledgements}

This study was supported partly by grants from the Ministry of Education, Culture, Sports, Science and Technology, Japan, to H. K. (19770008) and to M. F. (16370014). We thank T. Iwata for donating the sample of lake water.

\section{References}

Drobner, E., Huber, H., Rachel, R. \& Stetter, K. O. (1992). Thiobacillus plumbophilus spec. nov., a novel galena and hydrogen oxidizer. Arch Microbiol 157, 213-217.

Elsaied, H. \& Naganuma, T. (2001). Phylogenetic diversity of ribulose-1,5-bisphosphate carboxylase/oxygenase large-subunit genes 
from deep-sea microorganisms. Appl Environ Microbiol 67, 17511765.

Gonzalez, J. M. \& Saiz-Jimenez, C. (2002). A fluorimetric method for the estimation of $\mathrm{G}+\mathrm{C} \mathrm{mol} \%$ content in microorganisms by thermal denaturation temperature. Environ Microbiol 4, 770773.

Kojima, H., Iwata, T. \& Fukui, M. (2009). DNA-based analysis of planktonic methanotrophs in a stratified lake. Freshw Biol 54, 15011509.

Kumar, S., Tamura, K. \& Nei, M. (2004). MEGA3: integrated software for molecular evolutionary genetics analysis and sequence alignment. Brief Bioinform 5, 150-163.

Lane, D. J. (1991). 16S/23S rRNA sequencing. In Nucleic Acid Techniques in Bacterial Systematics, pp. 115-175. Edited by E. Stackebrandt \& M. Goodfellow. Chichester: Wiley.

Meyer, B. \& Kuever, J. (2007a). Molecular analysis of the diversity of sulfate-reducing and sulfur-oxidizing prokaryotes in the environment, using aprA as functional marker gene. Appl Environ Microbiol 73, 7664-7679.

Meyer, B. \& Kuever, J. (2007b). Molecular analysis of the distribution and phylogeny of dissimilatory adenosine- $5^{\prime}$-phosphosulfate reductase-encoding genes (aprBA) among sulfur-oxidizing prokaryotes. Microbiology 153, 3478-3498.

Meyer, B., Imhoff, J. F. \& Kuever, J. (2007). Molecular analysis of the distribution and phylogeny of the soxB gene among sulfur-oxidizing bacteria - evolution of the Sox sulfur oxidation enzyme system. Environ Microbiol 9, 2957-2977.

Nelson, D. M., Ohene-Adjei, S., Hu, F. S., Cann, I. K. \& Mackie, R. I. (2007). Bacterial diversity and distribution in the holocene sediments of a northern temperate lake. Microb Ecol 54, 252-263.

Thompson, J. D., Gibson, T. J., Plewniak, F., Jeanmougin, F. \& Higgins, D. G. (1997). The CLUSTAL_X windows interface: flexible strategies for multiple sequence alignment aided by quality analysis tools. Nucleic Acids Res 25, 4876-4882.

Throbäck, I. N., Enwall, K., Jarvis, A. \& Hallin, S. (2004). Reassessing PCR primers targeting nirS, nirK and nos $Z$ genes for community surveys of denitrifying bacteria with DGGE. FEMS Microbiol Ecol 49, 401-417.

Widdel, F. \& Bak, F. (1992). Gram-negative mesotrophic sulfatereducing bacteria. In The Prokaryotes, 2nd edn, vol. 4, pp. 3352-3378. Edited by A. Balows, H. G. Trüper, M. Dworkin, W. Harder \& K. H. Schleifer. New York: Springer. 